\title{
CORPOS QUE FALTAM
}

http://dx.doi.org/10.11606/issn.2175-3180.v13i25p318-321

Tatiana Piccardi ${ }^{\mathrm{I}}$

[...] The word corporeality is best thought of as 'corpo-reality' rather than 'corporeal-ity' as the familiar rules of English morphology would make us expect.

It is all about reality; or, if you like, the million-dollar question as to what the ultimate reality is all about. [...]

Kanavillil Rajagopalan, 'Corporeality' in metaphor studies: why it is so easy to miss the point ${ }^{1}$

\author{
[...] \\ Se tento dele afastar-me, \\ por abstração ignorá-lo \\ volta a mim, com todo o peso \\ de sua carne poluída \\ seu tédio, seu desconforto. \\ Quero romper com meu corpo, \\ quero enfrentá-lo, acusá-lo, \\ por abolir minha essência, \\ mas ele sequer me escuta \\ e vai pelo rumo oposto. \\ [...]
}

Carlos Drummond de Andrade, As contradições do corpo ${ }^{2}$

\footnotetext{
${ }^{\mathrm{I}}$ Universidade de São Paulo, São Paulo, Brasil.

1 Artigo publicado na revista DELTA, v. 26, número especial, São Paulo, 2010.

2 Poema publicado em Corpo, novos poemas, São Paulo, Record, 1984.
} 
Depois de um ano de pandemia, já "acostumada" ao isolamento e ao trabalho remoto, Lúcia se deu conta de que estava descobrindo as respostas a inquietações que nesse percurso vira e mexe apareciam, como: nossa, por que será que a grande maioria de meus amigos não tem demonstrado mais interesse em reuniões virtuais, em happy hour ou algo no gênero, para socializar um pouco e matar as saudades? Ou ainda: por que, ainda que haja algum tempo livre, muitos evitam videochamadas, individuais ou em grupo, que no começo da pandemia pareciam uma boa alternativa? Por que as pessoas se queixam de cansaço ou desmotivação no final do dia, ainda que as várias reuniões de trabalho virtuais tenham sido "produtivas", o que antigamente significava terminar o dia satisfeitos, e com um tipo de cansaço "bom"?

Lúcia foi se dando conta das respostas conforme percebia em si mesma os comportamentos que antes pareciam ser dos outros.

Primeiro percebeu que nos happy hours virtuais não conseguia ficar muito tempo no bate-papo. Depois de uma hora se cansava, o papo ficava sem graça, e acabava inventando uma desculpa para desconectar. Aí parou de dar desculpas, quando viu que alegar cansaço não era deselegante, já que todos sentiam a mesma coisa. Foi fácil concluir que se antes, nos barzinhos, eram capazes de ficar duas, três horas conversando, agora uma hora era o limite.

Para completar, depois de um dia de reuniões ou trabalhos realizados de forma remota, um happy hour, que nos tempos presenciais significava um jeito perfeito de relaxar, agora parecia mais uma obrigação nessa rotina incessante de criar e enviar links do zoom, google meet ou coisa que o valha, com o objetivo de juntar pessoas. Sim, apenas juntar pessoas. Foi vendo que não se tratava necessariamente de socializar, conviver, muito menos usufruir da companhia alheia. $O$ fato é que sua solidão e insatisfação difusa cresciam, na medida em que aumentavam o cansaço e a desmotivação.

E Lúcia observou-se lamentando-se. Viu que as reuniões de trabalho se tornaram, nesse mundo virtual, um mero local de resolução de problemas. De forma bem mais acentuada do que ocorria em reuniões virtuais entre amigos, ficaram de lado nesses encontros o momento do cafezinho, o momento das conversas paralelas, as falas de corredor. Nunca as pautas foram seguidas tão à risca. $O$ resultado em termos de produtividade podia ser até bom, mas a um custo que já começava a se 
revelar bem alto: a supressão do contato mais abrangente e profundo de uns com os outros.

O cansaço e a desmotivação para os encontros virtuais foram os primeiros sintomas de um problema maior: Lúcia conformou-se ao isolamento, ou, em outros termos, acostumou-se à ausência dos corpos. Quase não se lembrava de que são os corpos das pessoas com quem convivia que alimentavam suas emoções e lhe davam - ou não - o retorno afetivo de que precisava. Quase não se lembrava de que eram esses corpos, seus cheiros, sua aparência integral e tridimensional, o que vestiam, como comiam e como se moviam, seus trejeitos e manejos, sua textura, seu calor, sua cor, seu batimento cardíaco, seu suor, era a esses corpos que seu corpo respondia quando se encontravam. Surpreendeu-se ao constatar que interagia, de verdade, com corpos, mesmo na esfera "racional" do mundo do trabalho. Somos nossos corpos, e qualquer relacionamento que os suprima em algum momento será frustrado. Assim pensava Lúcia. Mas, enquanto pensava, se acostumava à frustração, salpicada de algumas doses de ansiedade, que era o jeito de seu corpo reclamar, mas Lúcia dificilmente o ouvia.

Naquele fim de tarde, Lúcia desligou o computador pontualmente às $18 \mathrm{~h}$, como fazia há vários meses. Fechou os olhos e massageou o pescoço dolorido. Levou alguns segundos para se ver de novo em um quarto de dormir, e não mais em um escritório que o pano de fundo do zoom caracterizava tão bem. $\mathrm{O}$ ato de desligar o computador era o ato de transitar rapidamente da realidade virtual para a realidade real. Era hora de preparar o jantar de sua mãe.

No caminho da cozinha, aproximou-se da porta do quarto da mãe, espiando com cuidado para ver se estava tudo bem. Naquele momento, a mãe cochilava, fazendo uns barulhos estranhos ao respirar que Lúcia simplesmente odiava. A mãe era uma velha senhora acamada e muito debilitada, ainda que bastante lúcida para a idade. Para aquela mulher inerte na cama, seu corpo era claramente uma barreira. Era uma barreira porque se impunha entre ela e o mundo, ainda que fosse um mundo menos mundo e mais imaginação de mundo. Em sua imaginação de mundo, via seu corpo extrapolar fronteiras, fronteiras entre sala e quarto, seu pequeno e grandioso mundo real.

Lúcia encostou no batente da porta semiaberta e olhou, olhou longamente, despreocupando-se momentaneamente com o horário. Viu o corpo deitado se afastar da pessoa da mãe como se afastaram de si os 
amigos, agora virtuais. Viu com lucidez maior que a da mãe o corpo daquela velha senhora virtualizar-se, enquanto morria devagar e calmamente, calma pontuada por doses suportáveis de ansiedade e frustração. Virtualizar e morrer, estranha analogia, que ocorreu a Lúcia assim meio do nada. Do nada? A tosse seca da mãe cortou seus pensamentos e despertou a ambas. Era hora do jantar. O corpo ainda não lhes faltava.

Recebido em 21 de abril de 2021

Aprovado em 18 de novembro de 2021

Tatiana Piccardi

Mestre e Doutora em Letras pela Universidade de São Paulo. Fez pesquisa de pós-doutorado em Linguística na Universidade Estadual de Campinas.

Contato: tpiccardi@gmail.com

(D): https://orcid.org/0000-0001-5186-0690

A Revista Desassossego utiliza a Licença Creative Commons Attribution que permite o compartilhamento do trabalho com reconhecimento da autoria e publicação inicial neste veículo - Attribution-NonCommercial-NoDerivates 4.0 International (CC BY-NC-ND 4.0), e reconhece que os Autores têm autorização prévia para assumirem contratos adicionais separadamente para distribuição não-exclusiva de versão dos seus trabalhos publicados, desde que fique explicitado o reconhecimento de sua autoria e a publicação inicial nesta revista. 